\title{
Optimalisasi Kemampuan Berbicara Pada Anak Usia Dini
}

Received : 5 Maret 2019

Revised : 26 Maret 2019

Accepted : 1 April 2019

\author{
Ade Karunia Rizky Manurung \\ Program Pascasarjana Pendidikan Anak Usia Dini \\ Universitas Negeri Jakarta, Jalan Raya Rawamangun Muka \\ Jakarta Timur \\ Email: adekarunia14@gmail.com
}

\begin{abstract}
Abstrak. Penulisan artikel ini membahasa tentang kemampuan berbicara anak usia dini. Penelitian ini bertujuan untuk meminimalisir keterlambatan berbicara pada anak usia dini dengan mengoptimalkan pembelajaran pada anak usia dini dengan menstimulasi anak melalui media pembelajaran dan menambah literatur dalam meningkatkan kemampuan berbicara pada anak usia dini. Kemampuan bernbicara merupakan kemampuan seseorang dalam mengungkapkan, menyampaikan, mengeksperiskan dan mengucapkan sesuatu yang ada dipikiran dan perasaan seseorang. Kemampuan berbicara memiliki peran yang penting dalam keberhasilan bersosialisasi seseorang, karena melalui kemampuan berbicara seseorang dapat berkomunikasi dan berinteraksi dengan orang yang ada disekitarnya.
\end{abstract}

Kata kunci: Kemampuan Berbicara, Pendidikan Anak Usia Dini, Media Pembelajaran

\section{Pendahuluan}

Perkembangan pada anak usia dini memuat aspek-aspek perkembangan yang dapat dikembangkan melalui lembaga pendidikan, yaitu PAUD. Pendidikan anak usia dini merupakan pendidikan yang dilakukan dengan memberikan berbagai rangsangan untuk membantu pertumbuhan dan perkembangan anak baik jasmani maupun rohani agar diri anak memiliki kesiapan untuk memasuki jenjang pendidikan berikutnya.

Melalui Pendidikan anak usia dini, diharapkan anak dapat mengembangkan seluruh potensi yang terdapat dalam diri anak yang meliputi pada pengembangan moral, dan nilai-nilai agama, fisik, sosial, emosional, bahasa, seni, dan keterampilan yang terdapat dalam diri anak. Salah satu aspek perkembangan anak usia dini adalah aspek perkembangan bahasa.

Hal ini sejalan seperti yang tertera di Permendikbud nomor 137 tahun 2014 tentang standar nasional pendidikan anak usia dini, yang didalam poin standar isi tingkat pencapaian perkembangan anak tentang aspek bahasa menguraikan bahwa keaksaraan mencakup pemahaman terhadap hubungan bentuk dan bunyi huruf, meniru bentuk huruf, serta memahami kata dalam cerita. Bahasa merupakan alat komunikasi seseorang untuk menyampaikan dan mengungkapkan pikiran dan perasaannya terhadap orang yang ada disekitarnya.

Perkembangan kemampuan bahasa seseorang harus dirangsang sejak dini agar kemampuan berbahasa pada manusia dapat berkembang secara optimal sesuai dengan tahap usia anak. Kemampuan bahasa sangat perlu diberikan penanganan yang tepat dapat berkembang sesuai dengan tahapan usia seseorang. Keberhasilan perkembangan bahasa dapat mempengaruhi kemampuan membaca, menyimak, menulis dan kemampuan berbicara. Kemampuan bahasa dalam diri anak harus diberikan pelatihan salah satunya kemampuan berbicara yang dapat membuat 
perbendaharaan kosa kata bertambah agar anak tidak mengalami kesulitan saat berkomunikasi dengan orang yang ada disekitarnya.

Anak yang dapat berbicara dengan baik akan mengantarkan kepada anak yang memiliki rasa percaya diri yang tinggi Sehingga mendorong kepada kemampuan kognitif yang dimiliki anak. Slain itu, anak yang memiliki perkembangan kemampuan berbicara yang baik akan menghindari anak dari speech delay.

Seperti yang terdapat dari hasil penelitian yang dilkukan oleh Pourfarhad mengenai perkembangan literasi yang dikaitkan dengan kemampuan menyimak dan berbicara mahasiswa di perguruan tinggi berpengaruh terhadap pencapaian akademik diperguruan tinggi. Hal ini dikarenakan oleh kegiatan perkuliahan yang mayoritas diisi oleh kegiatan diskusi yang didalamnya menuntut kemampuan dalam mendengarkan dan memberikan pendapat dengan baik Error! Reference source not found..

Selain itu, penelitian lain yang dilakukan oleh Raban dan Coates tentang perkembangan bahasa anak, menyatakan bahwa pengembangan ke aksaraan pada anak sangat penting dan terjadi melalui suatu percobaan dalam kehidupannya selama seumur hidup seseorangError! Reference source not found.

Penelitian diatas juga sejalan dengan hasil penelitian Bonamy dan Leonard mengemukakan bahwa anak-anak yang kurang memiliki kompetensi dalam berkomunikasi dengan cara tertentu yang tidak sesuai dengan konteksnya cenderung memiliki masalah keteranpilan sosialError! Reference source not found.. Hal ini yang dapat menyebabkan anak akan susah dapat berinteraksi dengan orang yang ada disekitarnya yang menjadikan anak menjadi anak yang pendiam sehingga kemampuan berbicara anak tidak berkembang secara optimal. Dari hasil penelitian yang telah dipaparkan diatas dapat diketahui bahwa kemampuan berbicara sangat berperan penting dalam meningkatkan potensi-potensi dalam diri anak.

Namun penulis menemukan fakta di TK Gudiseju, anak kelompok A yang berusia 4-5 tahun mengalami permasalahan dalam kemampuan berbicara. Dapat dikatakan kemampuan berbicara anak pada kelas A ini mengalami permasalahan, karena anak tidak dapat mengutarakan pemikirannya saat anak diminta untuk menceritakan pengalamannya dan anak belum mampu mengucapkan kosa kata dengan jelas. Peneliti melakukan wawancara dengan guru kelas A di TK tersebut dan menemukan akibat dari permasalahan kemampuan berbicara pada anak. salah satu akibatnya, yaitu kurang bervariasinya media pembelajaran yang digunakan dalam kegiatan pembelajaran berlangsung.

Dari permasalahan yang ditemukan peneliti, peneliti berkolaborasi dengan guru dalam pengoptimalisasian kemampuan berbahasa anak, Salah satunya kemampuan berbicara anak melalui media pembelajaran. Prinsipnya, media yang akan digunakan tersebut dapat menumbuhkan rasa semangat atau motivasi anak usia dini untuk dapat belajar dengan mudah dan menyenangkan sehingga mereka tidak merasa jenuh atau bosan dalam mengikuti proses pembelajaran. Selain itu, penggunaan media harus didasarkan pada tujuan pembelajaran yang hendak dicapai pada saat proses pembelajaran berlangsung. Salah satu media pembelajaran yang dapat membantu meningkatkan kemampuan berbicara anak yaitu media flipchart.

Hal ini sejalan dengan penelitian-penelitian relevan yang dilakukan oleh Ayuningtyas (2016) yang menunjukkan bahwa pemanfaatan media pembelajaran 
dapat mendorong keberhasilan kegiatan pembelajaran dalam meningkatkan kemampuan bahasa pada anak usia dini yang dapat dilhat dari hasil persentase penelitian tersebut. Selanjutnya penelitian oleh Error! Reference source not found. dengan judul " Penigkatan Kemampuan Berbicara Anak Usia Dini Melalui Media Pembelajaran Celemek Berkarakter”. Pada hasil penelitian ini menunjukkan media pembelajaran dapat mempengaruhi keberhasilan perkembangan kemampuan berbicara anak dengan hasil yang menunjukkan pada siklus I sebesar $75 \%$ dan siklus II $98 \%$ yang dapat dilihat terdapat peningkatan dalam kemampuan berbicara anak.

Artikel ini ditulis dengan tujuan untuk membahas hal-hal yang terkait dengan pengoptimalisasian kemampuan berbicara pada anak usia dini.

\section{Pembahasan}

\subsection{Kemampuan Berbicara Anak Usia Dini}

Perkembangan kemampuan berbicara sangat dipengaruhi oleh jumlah dan kualitas pembicaraan yang dilakukan orang tua dengan anak-anak mereka. Menurut Bromley mendefinisikan bahasa sebagai simbol yang teratur untuk mentransfer berbagai ide maupun informasi yang terdiri atas simbol-simbol visual maupun verbal Error! Reference source not found.. Selanjutnya, menurut Hurlock berbicara merupakan bentuk bahasa yang menggunakan artikulasi atau kata-kata yang digunakan untuk menyampaikan maksud Error! Reference source not found.. Hal ini yang membuat kemampuan berbicara merupakan bentuk komunikasi yang paling efektif, penggunaanya paling luas dan paling penting dalam kehidupan.

Selanjutnya, Chaney menyatakan berbicara kemampuan berbicara dinyatakan sebagi bentuk dari ngungkapan seseorang dalam menyampaikan dan menyatakan seseutu yang ada dalam pikiran dan perasannya dengan menggunakan simbol verbal maupun non verbal dalam berbagai konteks Error! Reference source not found..

Dari pendapat para ahli diatas, dapat disimpulkan bahwa kemampuan berbicara anak sangatla penting dikembangkan sejak dini karena kemampuan berbicara anak merupakan kemampuan yang dapat mempengaruhi kemampuan kognitif pada anak.

\subsection{Tahap Kemampuan Berbicara Anak Usia 4-5 Tahun}

Perkembangan kemampuan berbicara memiliki posisi yang penting dalam kehidupan seseorang. Kemampuan berbicara dapat dikembangkan sejak dini agar kemampuan berbicara akan berhasil sesuai dengan tahap perkembangan anak.

Menurut Jalango Error! Reference source not found. membagi tahap perkembangan anak menjadi lima tahapan yaitu: 1)Prelingusitik Speech (Berbicara melalui suara tetapi tanpa kata-kata usia 0-11 bulan), 2) linguistic Speech (Berbicara dengan satu ucapan kata usia 12-18 bukan), 3) making words into Phrases (Membuat kata menjadi frase usia 2-3 tahun), 4) using Complate Sentences (Menggunakan kalimat komplit usia 4-6 tahun) dan using Language Symbolically reading and writing (menggunakan bahasa secara simbolik usia 68 tahun).

Selanjutnya, Error! Reference source not found. menyatakan ada 6 tahapan perkembangan bahasa pada anak, yaitu : 1) Tanggapan bayi terhadap bahasa. 
kemampuan berbicara pada bayi dapat di pengearuhi pada saat bayi mendengarkan orang yang ada disekitarnya bicara atau suara musik. 2) vokalisasi. Bayi yang berumur 3 atau 4 bulan mulai mengoceh atau sering disebut pada tahap babbling. Ocehan-cehan bayi ini lama-kelamaaan akan menjadi suatu kata seiring dengan tahap perkembangannya.3) Pengembangan kata. pada tahap ini anak mulai dapat membedakan suara orang berbicara dengan bunyi-bunyian yang ada disekitarnya. 4)kalimat. Pada tahap ini anak sudah mulai dapat menggunakan kalimat sederhana alam kehidupannya seharihari. 5)Elaborasi. Pada tahap ini kemampuan anak dalam membuat kalimat sederhana semakin meningkat. Anak sudah dapat membuat kalimat yang lebih panajng dan anak sudah dapat berkomunikasi dengan orang yang ada disekitarnya. 6)Representasi grafis. Pada akhir masa prasekolah, anak sudah mulai menyadari pentingnya perkembangan bahasa yang terdapat dalam dirinya. Serta anak telah menyadari bahwa membaca dan menulis sebagai wujud dari bahasa.

Dari pemaparan tahap-tahap perkembangan kemampuan berbicara anak dapat disimpulkan bahwa setiap perkembangan yang terdapat dalam diri seseorang memiliki tahapannya masing-masing yang menuju kepada keberhasilannya di masa yang akan datang. Halnya ini dengan tahap perkembangan kemampuan bahasa anak yang dimulai sejak dini yang belum dapat berbicara sehingga dapat berbicara dan berkomunikasi dengan orang yang ada disekitarnya.

\subsection{Aspek -aspek Kemampuan Berbicara Pada Anak Usia Dini}

Dalam perkembangan kemampuan berbicara anak memiliki beberapa aspek yang terdapat dalam perkembangan ini. berikut ini menurut Error! Reference source not found. ada 5 aspek perkemabangan kemampuan berbicara pada anak, yaitu ketetapan bunyi hutu-huruf vokal dan konsonan dalam pengucapannya, penggunaan intonasi yang tepat, pemahaman si pembicara atas bahasa yang digunakannya, pengucapan kata-kata dalam bentuk dan urutan yang tepat dan tingkat kewajaran atau kelancaran yang tercermin sat seseorang berbicara.

Selanjutnya, menurut Kurikulum berbasis kompetensi TK yang dikeluarkan Depdiknas, kemampuan berbicara terdiri dari beberapa tahap, yaitu kosa kata, sintaksis, semantik dan fonem.

Dari pendapat tersebut dapat dipahami, bahwa dalam menilai kemmapuan berbicara pada anak dapat dilihat dari aspek pelafalan, tat bahasa, kosa kata, kefasihan, isi pembicaraan, dan pemahaman anak.

\subsection{Media Pembelajaran}

Dalam menunjang kebutuhan para anak-anak dalam mengembangkan potensipotensi yang dimilikinya dapat dilakukan dengan kegiatan pembelajaran yang bersifat menyenangkan. selain kegiatan pembelajaran yang dilakukan bersifat menyenangkan, kegiatan pembelajaran juga harus menyiapkan media-media pembelajaran yang membantu proses kegiatan pembelajaran berjalan baik yang berdampak positif dalam perkembangan anak.

Menurut Association for Education and Communication Technology (AECT), mengartikan media sebagai bentuk yang digunakan untuk menyampaikan informasi. Sedangkan Education Association (NEA), mengartikan media sebagai benda yang dapat dimanipulasi, dilihat, didengar, dibaca beserta 
instrument yang dipergunakan baik dalam kegiatan proses pembelajaranError! Reference source not found.. Selanjutnya menurut Error! Reference source not found. media pembelajaran merupakan suatu bagian yang integral dari suatu proses pendidikan disekolah.

Media pembelajaran memiliki tujuan untuk membantu anak dapat memahami kegiatan yang dilakukan dalam mengembangkan potensi-potensi yang terdapat dalam diri anak Error! Reference source not found.

Berdasarkan uraian diatas dapat disimpulkan media pemeblajaran merupakan alat bantu bagi seorang tenaga pendidik dalam mewujudkan proses pembelajaran yang menyenangkan bagi anak sehingga dapat membatu perkembangan anak.

\subsection{Media Flipchart}

Media pembelajaran flipchart merupakan media yang akan digunakan peneliti dalam meningkat kemmapuan berbicara anak. Menurut Sadiman flipchart merupakan media yang menyajikan informasi, bagian-bagian dari pesan ditulis dan dituangkan dalam lembaran tersendiri, kemudian lembaran-lembaran tersebut dibundel jadi satu persatu dengan bagian pesan yang disampaikan Error! Reference source not found.

Menurut Susilana flipchart adalah lembaran-lembaran kertas menyerupai album atau kalender berukuran 50x75 cm, atau ukuran yang lebih kecil $21 \times 28 \mathrm{~cm}$ sebagai flipbook yang disusun dalam urutan yang diikat pada bagian atasnya Error! Reference source not found.. Dalam penggunaan media flipchart dapat menyajikan pesan pembelajaran secara ringkas, praktis, bertahap serta merupakan media yang murah dalam pembuatannya, penyajian dengan flipchart dapat digunakan diluar ruangan kelas, dan yang terakhir media flipchart dapat membantu mengatasi rasa bosan yang terjadi pada saat kegiatan pembeajaran Error! Reference source not found.

Berdasarkan uraian diatas dapat disimpulkan bahwa media flipchart merupakan media pembelajaran yang terdiri dari selembar kertas yang berisikan topik yang telah disediakan oleh pendidik dalam proses kegiatan pembelajaran.

\subsection{Langkah-langkah Pembelajaran menggunakan Media Flipchart}

Berikut ini langkah-langkah pembelajaran menggunakan flipchart dalam kegiatan pembelajaran, yaitu: 1)Mempersiapkan diri. Seorang pendidik harus mengusai materi yang tercantum dalam flipchart tersebut agar guru dapat menyampaikannya dengan baik dan menarik sehingga anak dapat mengikuti kegiatan pembelajaran dengan baik. 2) Penempatan yang tepat. Memberikan posisi penempatan flipchart agar dapat dilihat dengan baik oleh anak yang ada didalam kelas. 3) Pengaturan tempat duduk anak. tempat duduk anak diatur sedemikian rupa agar anak dapat melihat media flipchart dengan jelas. 4)Perkenalkan pokok materi. Materi yang disajikan terlebih dahulu diperkenalkan kepada anak pada saat awal pembelajaran. 5) Sajikan gambar. Setelah masuk pada materi, pendidik memulai memperlihatkan lembaranlembaran gambar flipchart dan memberikan keterangan yang cukup terhadap gambar. 6)Beri kesempatan anak untuk bertanya. Pendidik memberikan stimulus agar anak mau bertanya. 7) Menyimpulkan materi. Dorong anak 
berperan aktif menyimpulkan materi yang diperkuat oleh pendidik Error! Reference source not found.

Dengan demikian agar media flipchart dapat diterapkan dikegiatan pembelajaran pada anak usia dini harus sesuai dilakukan dengan langkahlangkah yang telah dipaparkan diatas.

\subsection{Optimalisasi kemampuan berbicara anak melalui media flipchart}

Berdasarkan hasil kajian dari studi literatur diatas yang mencakup tentang berpengaruhnya media pembelajaran terhadap kemampuan berbahasa anak, yaitu kemampuan berbicara anak. Media pembelajaran dibuktikan dapat membantu proses kegiatan pembelajaran pada anak usia dini. Hal ini sesuai dengan penelitian-penelitian relevan yang telah dilakukan oleh peneliti sebelumnya. Media pembelajaran juga dapat mendorong dan menumbuhkan minat anak dalam mengikuti kegiatan pembelajaran dalam mengembangkan kemampuan-kemampuan yang terdapat dalam diri anak salah satunya kemampuan berbicara anak. Kemampuan berbicara merupakan kemampuan dalam menyampaikan dan mengungkapkan suatu yang dipikirkan.

Dalam mengoptimalisasikan kemampuan berbicara pada anak dapat dilakukan melaui media flipchart. Media flipchart yang isi yang telah disediakan oleh peneliti dan guru dalam membantu meningkatkan kemampuan berbicara anak. media flipchart di desain semarik mungkin yang membuat minat belajar anak bertambah sehingga kemampuan berbicara anak dapat berkembang dengan baik sesuai dengan tahap perkembangannya.

Hal ini diperkuat oleh hasil penelitian yang telah dilakukan oleh Marsita,Anggria Negara, Oka, dkk yang berjudul "Penerapan Metode Bercerita Berbantuan Media Flipchart Dapat Mengambangkan Kemampuan Berbahasa Lisan Anak Usia 5-6 Tahun" yang membuktikan bahwa kemampuan berbahasa lisan anak meningkat setelah menerapkan media flipchart dalam kegiatan pembelajaran.

\section{Kesimpulan}

Kemampuan berbicara merupakan kemampuan individu dalam berkomunikasi dan menyampaiakn segala hal yang terdapat dalam pikiran dan perasaannya agar orang yang ada disekitarnya mengetahui apa yang ia butuhkan dan apa yang ia ingin sampaikan. Kemampuan berbicara juga memiliki pengaruh terhadap perkembangan akademik seseorang. Hal ini dikarenakan anak yang memiliki kemampuan berbicara yang baik dapat melakukan kegiatan diskusi dan menyampaikan hasil yang telah didiskusikan dengan jelas dan dapat dimengerti oleh pendengar. Maka dari itu, pentingnya optimalisasi kemampuan berbicara pada anak usia dini.

Salah satu pengoptimalisasian kemampuan berbicara anak dilakukan dengan media pembelajaran flipchart yang dapat menarik minat anak dalam memperhatikan kegiatan pembelajaran berlangsung. media flipchart merupakan lembaran yang sama ukurannya dijilid menjadi satu secara baik yang didalamnya telah didesain oleh peneliti dan guru agar dapat digunakan dalam meningkatkan kemampuan berbicara pada anak.

\section{Daftar Rujukan \\ Error! No bookmark name given.}

